\title{
A Study on Perception of Researchers of KVASU during Lockdown Period
}

\author{
Shreyansh Hosure* and T. S. Rajeev \\ Department of Veterinary and Animal Husbandry Extension, College of Veterinary and \\ Animal Sciences, Mannuthy, Kerala, India \\ *Corresponding author
}

\begin{tabular}{l} 
Key w o r d s \\
COVID-19, \\
Lockdown, \\
Perception and \\
Researchers \\
\hline Article Info \\
\hline $\begin{array}{l}\text { Accepted: } \\
\text { 22 June } 2020 \\
\text { Available Online: } \\
\text { 10 July 2020 }\end{array}$ \\
\hline
\end{tabular}

\section{A B S T R A C T}

The aim of this study is to know the perception of researchers of Kerala Veterinary and Animal Sciences University (KVASU) during lockdown period. The entire postgraduates and doctoral students doing research in KVASU were taken for the study. Among them 88.39 per cent of researchers had responded for this survey. The results from the study found that majority of the researchers are in the mid stage of their research and most of them perceived that COVID-19 has affected their research work. With respect to perception statements majority of researchers perceived that lockdown has created many barriers for researcher to proceed with their research work and 82.83 per cent of researchers perceived that thesis making guidelines should be made more lenient by the university. Further majority $(79.80 \%)$ of researchers perceived that advisory committee should be made flexible in supporting the research work during post lock down period. As a consequence, appropriate strategies need to be adopt by the university and flexibility has to be made for carrying out research work. On this study majority of researchers perceived that the study covered the complete mind reading aspect of the researchers and they are hoping that responses and suggestions given by them will be taken into consideration for taking necessary action.

\section{Introduction}

Corona virus pandemic has not only impacted human life but also impacted education system (Chick et al., 2020). With principles of social distancing, all face to face classes were suspended due to the ongoing COVID-19 pandemic (Ferrel and Ryan, 2020). The
COVID-19 pandemic has affected educational system worldwide. It has forced educational institutions to close, which has impacted over $90 \%$ of the world's student population.

In line with the national lockdown put in place by government at midnight on Tuesday day 24 March, to stop the spread of COVID- 
19, the university has put on hold all research being done on campus whether in the laboratory, in the studio or in the field. This unique situation raises a number of concerns and uncertainties for the research community. As an institution and as a country, we must keep the virus's spread to a minimum by obeying the restrictions of the lockdown period requiring us all to stay at home along with some three billion people globally and the social distancing that will continue beyond it.

COVID pandemic made us to realize that importance of online education for students. Students' satisfaction levels with online learning were comparable to the previous studies. It is recognized that challenges created by the COVID-19 pandemic provided great uncertainty and anxiety for researchers who are unable to proceed with aspects of their projects for the moment and have timelimited funding (Scagnoli et al., 2019).

Before making any change in the existing system of university, it is necessary to know the perception of researchers and their needs. Hence, this investigation was conceived with the objective of studying the perception of researchers during lockdown period.

\section{Materials and Methods}

An ex-post-facto research design was adopted for the study. The entire postgraduates and doctoral students doing research in Kerala Veterinary and Animal Sciences University (KVASU) were taken for the study. Among them 88.39 per cent of researchers has responded for the survey. A structured Google form was prepared under expert guidance and data collection was done through using purposive sampling technique through sharing link on the social media. Collected data were analyzed using statistical tools viz. frequency and percentage.

\section{Results and Discussion}

\section{Academic profile of researchers studying in KVASU}

The academic profile of researchers studying in KVASU is given in the Table 1. Among the researchers those who responded for the survey majorities $(76.80 \%)$ of them are studying currently in the fourth semester followed by 18.20 per cent are studying in third semester. Regarding status of research majority $(53.50 \%)$ of researchers are in the mid stage of research followed by 24.20 per cent of researchers are in the initial stage of research and 18.30 per cent are in final stage of research. With respect to type of research majority $(56.60 \%)$ of researchers are doing laboratory experiments followed by 14.10 per cent are doing field experiments and 7.10 per cent of researcher doing survey research.

The reason for the above findings may be the study is purposively focusing on the researchers as the major part of the researchers will do research work in the $4^{\text {th }}$ semester.

\section{Protective measures taken by the researchers}

The protective measures taken by the researchers of KVASU are given in the Table 2. Majority $(73.70 \%)$ of researchers had protected themselves by taking all the three protective measures viz. staying at home, wearing personal protective equipment and by maintaining social distance followed by 18.20 per cent of researchers had protected themselves by only staying at home and 7.10 per cent are protected by wearing personal protective equipment. Regarding staying place majority $(87.90 \%)$ of researchers are staying at home followed by 10.10 percent are staying at hostel. 
The findings are in line with the measures initiated by the department of health and

family welfare Government of India (GOI, 2020).

Table.1 Academic Profile of Researchers Studying in KVASU

\begin{tabular}{|c|c|c|}
\hline Sl. No. & Academic Profile of researcher & Percentage \\
\hline \multirow[t]{6}{*}{$\mathbf{I}$} & $\begin{array}{l}\text { Current Semester of researchers } \\
\text { a) Semester I }\end{array}$ & 1.00 \\
\hline & b) Semester II & 2.00 \\
\hline & c) Semester III & 18.20 \\
\hline & d) Semester IV & 76.80 \\
\hline & e) Semester V & 1.00 \\
\hline & f) Semester VI & 1.00 \\
\hline \multirow[t]{5}{*}{ II } & $\begin{array}{l}\text { Status of researchers research } \\
\text { a) Yet to start }\end{array}$ & 4.00 \\
\hline & b) Initial Stage & 24.20 \\
\hline & c) Mid Stage & 53.50 \\
\hline & d) Final Stage & 18.30 \\
\hline & e) Completed & 0 \\
\hline \multirow[t]{4}{*}{ III } & $\begin{array}{l}\text { Type of research work } \\
\text { a) Laboratory Experiment }\end{array}$ & 56.60 \\
\hline & b) Field Experiment & 14.10 \\
\hline & c) Survey Research & 7.10 \\
\hline & d) Others & 22.20 \\
\hline
\end{tabular}

Table.2 Protective measures taken by the researchers

\begin{tabular}{|l|l|c|}
\hline Sl. No. & Protective Measures & Percentage \\
\hline I & $\begin{array}{r}\text { Protective measures taken during COVID-19 outbreak } \\
\text { a) Staying at home }\end{array}$ & \\
\hline & b) Wearing protective equipment & 7.20 \\
\hline & c) Maintaining social distance & 1.00 \\
\hline d) All the above & 73.70 \\
\hline & $\begin{array}{r}\text { Staying Place of researchers during pandemic } \\
\text { a) Home }\end{array}$ & 87.90 \\
\hline & b) Hostel & 10.10 \\
\hline c) Hotel & 0 \\
\hline d) Friends House & 1.00 \\
\hline e) Others & 1.00 \\
\hline
\end{tabular}


Table.3 Perception of researchers during lockdown period

\begin{tabular}{|c|c|c|c|c|}
\hline $\begin{array}{l}\text { Sl. } \\
\text { No. }\end{array}$ & Statement & $\begin{array}{c}\text { Disagree } \\
(\%)\end{array}$ & $\begin{array}{c}\text { Undecided } \\
(\%)\end{array}$ & $\begin{array}{c}\text { Agree } \\
(\%)\end{array}$ \\
\hline 1 & Work from home is best during lockdown & 36.36 & 15.15 & 48.49 \\
\hline 2 & COVID-19 has affected my research work & 15.15 & 5.05 & 79.80 \\
\hline 3 & Lockdown gave more time for preparation of research & 57.57 & 12.12 & 30.31 \\
\hline 4 & COVID-19 has made researchers to speed up their work than earlier & 79.80 & 9.09 & 11.11 \\
\hline 5 & $\begin{array}{l}\text { Reduction in number of working days in the upcoming semesters may } \\
\text { affect the researcher in maintaining quality of research }\end{array}$ & 16.16 & 14.14 & 69.70 \\
\hline 6 & Online mode of education is suitable only during lockdown & 44.45 & 15.15 & 40.40 \\
\hline 7 & $\begin{array}{l}\text { Lockdown has created many barriers for researcher to proceed with } \\
\text { research work }\end{array}$ & 12.12 & 6.06 & 81.82 \\
\hline 8 & $\begin{array}{l}\text { Thesis making guidelines should be made more lenient by the university } \\
\text { by comprehending the situation }\end{array}$ & 9.09 & 8.08 & 82.83 \\
\hline 9 & Need special concern for research from government & 11.11 & 3.03 & 85.86 \\
\hline 10 & $\begin{array}{l}\text { Initiatives taken by the government have helped me a lot during this } \\
\text { pandemic }\end{array}$ & 17.17 & 21.21 & 61.62 \\
\hline 11 & $\begin{array}{l}\text { Need more guidance from my Advisory Committee for completion of my } \\
\text { research work at the earliest }\end{array}$ & 16.16 & 11.11 & 72.73 \\
\hline 12 & $\begin{array}{l}\text { Support from family and friends is essential to work from home during } \\
\text { lockdown period }\end{array}$ & 16.16 & 8.08 & 75.76 \\
\hline 13 & Extension of fellowship is necessary till completion of my research work & 11.11 & 7.07 & 81.82 \\
\hline 14 & Expecting more support from my Advisor other than his suggestions & 17.17 & 13.13 & 69.70 \\
\hline 15 & $\begin{array}{l}\text { COVID-19 has created new opportunities for me in my career } \\
\text { development }\end{array}$ & 62.63 & 19.19 & 18.18 \\
\hline 16 & COVID-19 will affect my future career plan & 23.23 & 12.12 & 64.65 \\
\hline 17 & $\begin{array}{l}\text { Concession of research objective will help me to complete my research } \\
\text { work within stipulated time }\end{array}$ & 18.18 & 29.29 & 52.53 \\
\hline 18 & $\begin{array}{l}\text { Additional grants by the university will support the researcher during post } \\
\text { lockdown period in modifying and improving the research work }\end{array}$ & 13.13 & 14.14 & 72.73 \\
\hline 19 & $\begin{array}{l}\text { Reduction in sample size without affecting quality of research will help } \\
\text { me to complete my research work within available time period }\end{array}$ & 18.18 & 25.25 & 56.57 \\
\hline 20 & Delaying in start of college will not affect my research work & 68.69 & 13.13 & 18.18 \\
\hline 21 & $\begin{array}{l}\text { Advisory committee should be made flexible in supporting my research } \\
\text { work during post lock down }\end{array}$ & 11.11 & 9.09 & 79.80 \\
\hline 22 & $\begin{array}{l}\text { After lockdown Advisor should spend more time in my research which } \\
\text { will help me to complete research at the earliest }\end{array}$ & 13.13 & 16.16 & 70.71 \\
\hline 23 & Advisor should be flexible in correction of my thesis & 15.15 & 12.12 & 72.73 \\
\hline 24 & Final Viva-Voce should be conducted through videoconference & 31.31 & 29.29 & 39.40 \\
\hline 25 & University should grant permission to reframe my research work & 18.18 & 32.32 & 49.50 \\
\hline 26 & COVID-19 has made my research work complex & 21.21 & 23.23 & 55.56 \\
\hline 27 & COVID-19 has changed my future plans by extending semester & 12.12 & 11.11 & 76.77 \\
\hline 28 & Lockdown has reduced my interest in research work & 41.41 & 14.14 & 44.45 \\
\hline 29 & COVID-19 will create an impact on my honesty in research work & 50.51 & 20.20 & 29.29 \\
\hline 30 & COVID-19 will affect the ethics of the research study & 45.46 & 20.20 & 34.34 \\
\hline
\end{tabular}




\section{Perception of researchers during lockdown period}

Perception of researchers during lockdown period is given in the table 3 . The data from the study revealed that majority $(79.80 \%)$ of researchers had perceived that COVID-19 has affected their research work and only 48.49 per cent of researchers had perceived that work from home is best during lock down period.

Majority (79.80\%) of researchers had disagreed that COVID-19 has made researchers to speed up their work than earlier and more than $(57.57 \%)$ half of the researchers had disagreed for lockdown gave more time for research preparation.

A perusal from the Table 3 revealed that majority $(81.82 \%)$ of researchers perceived that lockdown has created many barriers for researcher to proceed with research work and 69.70 per cent of researchers had perceived that reduction in number of working days in the upcoming semesters may affect the researcher in maintaining quality of research.

The data from the table indicated that about 82.83 per cent of researchers had perceived that thesis making guidelines should be made more lenient by the university by comprehending the situation and 85.86 per cent of researchers perceived that need special concern for research from government. Regarding the statement initiatives taken by the government have helped researcher a lot during this pandemic more than half $(61.62 \%)$ of the researchers had agreed for it.

Among all the researchers those who responded for the survey majority $(72.73 \%)$ of them perceived that they need more guidance from advisory committee for completion of their research work at the earliest and 69.70 per cent of researchers had agreed that expecting more support from their advisor other than his suggestions. About half $(52.53 \%)$ of researchers perceived that concession of research objective will help them to complete their research work within stipulated time.

It was noticed from the study that more than half $(56.57 \%)$ of the researchers had perceived that reduction in sample size without affecting quality of research will help them to complete their research work within available time period and 68.69 per cent of researchers had disagreed for delaying in start of college will not affect their research work.

It was evident from the study that majority $(79.80 \%)$ of researchers had perceived that advisory committee should be made flexible in supporting their research work during post lock down period and 70.71 per cent of researchers perceived that after lockdown advisor should spend more time in their research which will help them to complete research work at the earliest. About 72.73 per cent of researchers perceived that advisor should be flexible in correction of their thesis and 39.40 per cent of researchers have agreed for Final Viva-Voce should be conducted through videoconference.

It was perused from the study that most $(81.82 \%)$ of researchers had perceived that extension of fellowship is necessary till completion of their research work and 72.73 per cent were perceived that additional/special grants by the university will support them during post lockdown period in modifying and improving the research work.

It was observed from the study that almost half $(49.50 \%)$ of the researchers had perceived that University should grant permission to reframe the research work and more than half $(55.56 \%)$ of researchers had perceived that COVID-19 has made their research work complex. 
The data furnished in Table 3 found that majority $(75.76 \%)$ of researchers had perceived that support from family and friends are essential to work from home during lockdown period and 62.63 per cent of researchers had disagreed for COVID-19 has created new opportunities for them in their career development. More than half $(64.65 \%)$ of the researchers perceived that COVID-19 will affect their future career plan.

A glance at the Table 3 revealed that majority (76.77\%) of researchers felt that COVID-19 has changed their future plans by extending the semester and 44.45 per cent of researchers perceived that lockdown has reduced their interest in research work. Exactly half $(50.51 \%)$ of the researchers had disagreed that COVID-19 will create an impact on researcher honesty in research work and 45.46 per cent of researchers disagreed for the statement COVID-19 will affect the ethics of the research study.

The reason for the above perceptions may be majority of researchers are in mid stage of research and they need to complete research work at the earliest as many of them have been waiting to join $\mathrm{PhD}$, get job and appearing for competitive exams as the start of college is still indefinite their perception goes like this.

The result from the study concluded that most of the researchers perceived that lockdown has created many barriers for researcher to proceed with the research work and thesis making guidelines should be made more lenient by the university. The majority of researchers felt that advisory committee should be made flexible in supporting their research work during post lock down period and extension of fellowship is necessary till completion of research work with special grants from the university. On this study majority of researchers perceived that the study covered the complete mind reading aspect of the researcher and they are hoping that responses given by them will be taken into consideration for taking necessary action.

\section{References}

Chick, R. C., Clifton, G. T., Peace, K. M. et al., 2020. Using technology to maintain the education of residents during the COVID-19 pandemic. J. Surg. Educ.

Ferrel, M. N. and Ryan, J. J. 2020. The impact of COVID-19 on medical education. Cureus. 12.

Government of India. 2020. Department of Health and family welfare. https://www.mohfw.gov.in/pdf/Measure sUndertakenToEnsureSafetyOfHealthW orkersDraftedForCOVID19Services.pdf 20 April, 2020.

Scagnoli, N. I., Choo, J., Tian, J. et al. 2019. Students' insights on the use of video lectures in online classes. Br. J. Educ. Technol. 99-414.

\section{How to cite this article:}

Shreyansh Hosure and Rajeev, T. S. 2020. A Study on Perception of Researchers of Kvasu during Lockdown Period. Int.J.Curr.Microbiol.App.Sci. 9(07): 2868-2872.

doi: https://doi.org/10.20546/ijcmas.2020.907.339 